\title{
Linguistic Proficiency and Strategies on Reading Performance in English
}

\section{Seyed Hassan Talebi}

Ph.D. in TEFL, University of Mazandaran, Iran, hstalebi@umz.ac.ir

General English (L2) proficiency and reading strategies are believed to be highly effective in successful reading performance. However, available studies rarely investigated the combined effects of these two variables on successful reading. To fill this gap, 78 university students were divided into four groups of different degrees of these two variables in L2 and given a reading test in English and an interview for assessing how much of the problems in L2 reading among the four groups were rooted in linguistic competence and/or strategic competence. Findings evinced that the high general proficiency level coupled with high awareness and use of reading strategies would result in best performance and that the pattern of answers to different components of reading question is different in different groups. It is concluded that both of the variables should be emphasized simultaneously for the best performance in reading comprehension.

Keywords: Combined effects, awareness and use of strategies, language proficiency, reading strategies, reading performance

\section{INTRODUCTION}

Grabe \& Stoller (2002, p.9) define reading ability as the efficiency of the reader, "to draw meaning from the printed page and interpret this information appropriately". Readers should actively participate in the reading process to construct text meaning. This makes reading an interactive process among readers, texts and tasks (Koda, 2005). In order to read effectively, readers need appropriate reading strategies. Urquhart and Weir (1998, p. 95) define reading strategies as "ways of getting around difficulties encountered while reading". Studies (e.g., Oxford et al., 1993) have shown the importance of reading strategies and language proficiency in successful reading performance. Regarding the mutual effects of lower level (e.g., word processing) or higher level (e.g., use of reading strategies for text comprehension) processing on each other in reading comprehension there are different views. Some researchers (e.g., Perfetti \& Hart, 2001) suggest that inefficiency in lower level processing inhibits higherlevel processes. on the other hand, other researchers (e.g., Walczyk, 2000) stress the role of higher level processing in reading comprehension and state that as readers employ strategies for processing, inefficiency in lower-level processing does not normally hinder reading comprehension. According to Phan (2006) strategic reading plays an essential part in removing reading difficulties and achieving comprehension goals. Research studies of the past three decades have shown the good effects of 
comprehension strategies on reading performance. Koda (2004) found that strategic reading would compensate for learners' comprehension problems and develop their critical thinking. Mokhtari \& Perry (2008) showed it was likely that greater awareness of reading strategies would lead to better reading comprehension. Other studies (e.g., Anderson, 1991; Brantmeier \& Dragiyski, 2009) also showed the use of strategies would differentiate between good and poor readers. However, in order to use reading strategies effectively, readers should reach a certain level of linguistic proficiency. In fact, studies (e.g., Alderson, 1984; Koda, 2005) showed lack of linguistic proficiency would shortcircuit effective strategy use. Many studies were conducted showing the relationship between language proficiency and strategy use. For example, Liu (2004) and Nisbet et al., (2005) found that more proficient language learners used a wider range of language learning strategies.

Contrary to the above studies, however, as has been shown by Eskey (2005) and Phan (2006) high proficiency level is not always a determining factor in coping with reading problems. In such cases, these students feel perplexed and cannot take an appropriate approach to improve their reading performance. (Shokrpour \& Fotovatian, 2009)

As was discussed above, most of the available studies found a strong relationship between English language proficiency and awareness and use of strategies in English reading comprehension. However, as an EFL teacher in Iran, I have observed students who are of a good linguistic ability but lack awareness and effective use of strategies for reading comprehension. These students are mostly those who rely more on the linguistic competence and are not aware of reading strategies or do not use them effectively. The reverse has also been observed. I had students who are poor in linguistic competence but have a good repertoire of reading strategies to compensate for linguistic deficiency for reading in L2 (English). Though there is a good number of research available on the relationship of reading strategies and language proficiency in English, researchers did not study the combined effects of different degrees of both general proficiency level and awareness and use of reading strategies on effective reading comprehension in L2 (English). Considering the fact that the balance between the two linguistic (general English proficiency) and cognitive (awareness and use of reading strategies) variables might be disturbed due to lack of strength in each of these variables or even due to overemphasis of one variable over another, this paper studies the combined effects of the two types of linguistic and strategic knowledge on efficient reading comprehension of Iranian EFL students. It also seeks two other purposes. One is to find out which of the reading comprehension question types are most/least affected as a result of the combination of awareness and use of strategies and level of general proficiency in English. Another purpose is to find out how much of the problems in L2 reading are rooted in linguistic competence and/or strategic competence.

Therefore, this study attempts to answer the following questions:

1- Is there any difference between the overall performance of different groups of combined general English proficiency and reading strategy awareness and use on reading comprehension test in English? 
2- What is the pattern of performance on different components of reading comprehension test (i.e., literal comprehension, inferencing, reorganizing, vocabulary problem solving) in different groups of combined general English proficiency and reading strategy awareness and use in English?

3- How much of the problems in L2 reading among the four groups are rooted in language proficiency and/or reading strategy awareness and use in English?

\section{METHOD}

\section{Subjects}

78 university students participated in this study. They were undergraduate freshmen who were admitted to the University of Mazandaran for full-time academic study in basic sciences. Background information collected at the beginning of the study indicated that $52.56 \%$ were male and $47.43 \%$ were female students and the age range was from 19 to 23. They agreed to participate in the research and found it interesting after the purpose and nature of the research was revealed to them. These students had studied English for 3 and 4 years at junior and senior high school levels, respectively. Therefore, they had an acceptable level of general English proficiency to pursue university-level course work without any language-related restrictions (Generally, they had to pass these courses with the minimum score of ten out of twenty). English courses at senior high school level are predominantly reading based. In order to come to this level of education at the University of Mazandaran, the students had to pass the entrance exam for state universities which is held nationwide each year. Therefore, this test functioned as a screening test for students to get admission to the University of Mazandaran.

\section{Instruments}

The following instruments were used in this study.

\section{Assessment of awareness and use of reading strategies}

The students' awareness and use of reading strategies was assessed through MARSI (Metacognitive Awareness of Reading Strategies Inventory) (Mokhtari \& Reichard, 2002). The instrument was originally designed to measure students' awareness and use of reading strategies while reading academic or school-related materials. MARSI is composed of thirty items in three broad categories of Global Reading Strategies, Problem-Solving Strategies and Support Reading Strategies. The instrument was given to 20 freshmen students at the University of Mazandaran, the faculty of basic sciences. The internal consistency reliability coefficient for the whole instrument (without calculating the reliability index for each of the three components separately), using the KR-21 formula was 0.88. However, the complete description of the psychometric properties as well as its theoretical and research foundations of the instrument can be found in Mokhtari \& Reichard (2002). The instrument was translated into Persian, the first language and academic language of the participants, so that the participants would feel more comfortable with the instrument and understand the items better. The translated version of the instrument along with its original version was submitted to two 
experts for the purpose of content validity. Items which were translated ambiguously were corrected in the final draft.

\section{Language Proficiency Test}

In order to make sure of the general English proficiency of the subjects, a test of Nelson, series $400 \mathrm{~A}$, was employed. It consisted of four parts: Reading comprehension, cloze passage, vocabulary, and pronunciation. All parts were in the form of multiple-choice questions. There were in all 50 items and the time allotted was 35 minutes. The test was piloted against a similar group of 15 students and the reliability of the test scores according to the KR-21 formula turned out to be .79 .

\section{Test of Reading Comprehension in English}

Day \& Park (2005) presented taxonomy of the types of comprehension questions believed to help students understand the text better by becoming interactive readers. They recommended six types (i.e., Literal comprehension, Reorganization, Inference, Prediction, Evaluation, Personal Response) of questions to be employed by teachers and material developers to help students become interactive readers. However, the first three types of comprehension questions were employed in this study as they were more objective for scoring purposes. Literal comprehension refers to an understanding of the direct and explicit meaning of the text, such as facts, vocabulary, dates, times, and locations. An example of a literal comprehension question about this article is: How many types of comprehension do the authors discuss? Reorganization is based on the literal understanding of the text. However, it is more complex than literal meaning comprehension type questions, as students should move from a sentence-by-sentence understanding of the text to a more global view. Readers must put together information collected from various parts of the text for more understanding. Answer to Inference questions are not explicitly stated in the text and are a combination of the literal understanding of the text with the readers' knowledge and intuitions.

In developing the test of reading comprehension in English four passages were selected from the reading section of books two and three of New Interchange series. The number of words in the selected four passages ranged from 257 to 295 words. Seven items were developed for each passage and in all there were twenty eight items. The reliability of the test of reading in English was also taken care of at the piloting stage through the KR21 formula which turned out to be .76 . To determine the concurrent validity of the test of reading, the correlation coefficient between the Nelson test of proficiency and the test of reading comprehension was calculated and turned out to be .84 which was suitable for the purpose of this study. The time allowed was 40 minutes as determined at the piloting stage.

\section{Interview protocol on reading}

In order to capture more in-depth information regarding the different problems that the participants from the four groups (See the procedure section for more information about the composition of the four groups) faced in reading, the researcher gave a one-on-one semi-structured interview with four participants, one from each group, using open-ended 
questions. The semi-structured interviews allow the researcher to negotiate meanings with the interviewees and give an opportunity for the researcher to probe for further and deeper information. The interview for each student took about 15 minutes. All interviews were audio recorded with the students' oral consent.

\section{Procedures}

Instruments were distributed to the students during the class hour. Students were informed of the objective of the study. Then, the researcher gave a description of the instruments, and explained how to complete them. First, through administering the Nelson test of proficiency to all participants, those whose scores were below (N: 42 students) and above (N: 36 students) the mean score were selected as low and high general English proficiency level students, respectively. (See Table 1)

Table 1: Descriptive statistics for the test of proficiency

\begin{tabular}{llll}
\hline Index & Mean & $S D$ & $N$ \\
\hline Nelson test & 28 & 5 & \multirow{2}{*}{78} \\
\hline English Reading questionnaire & 115.38 & 10.08 & \\
\hline
\end{tabular}

The next session they were given the reading strategies questionnaire as a measure for the participants to report their perceived strategies while reading in English. However, in the two groups of high and low proficiency levels, the perceived use of strategies was reported and from the obtained data in the two groups those whose scores were below and above the mean (115.38) were considered as low and high groups of strategy awareness and use, respectively. (See table 1) The following table (table 2) is the schematic presentation of the participants in the four groups.

Table 2: Schematic presentation of participants in four groups

\begin{tabular}{ll}
\hline Group & $N$ \\
\hline Group 1 (High proficiency high strategy use) & 19 \\
\hline Group 2 (High proficiency low strategy use & 17 \\
\hline Group 3 (Low proficiency high strategy use) & 23 \\
\hline Group 4 (Low proficiency low strategy use ) & 19 \\
\hline
\end{tabular}

Finally, after determining to which group the participants belonged in terms of having different combined degrees of linguistic proficiency and reading strategy awareness and use, the reading comprehension test was distributed.

For the quantitative phase of the study interviews were given for assessing how much of the problems in L2 reading among the four groups were rooted in linguistic competence and/or strategic competence. One student from each of the four groups was selected randomly for the interview. The interviews were conducted in Persian as both the participants and the researcher felt more comfortable and expressive in Persian and it was believed that more accurate data would be collected. The recordings were transcribed and translated from Persian to English language. In data analysis the data were coded and divided into segments with similar characteristics. To have more accurate and correct data, a colleague who is a Ph.D. in applied linguistics was asked to review transcriptions. 


\section{FINDINGS}

\section{Quantitative phase of the study for questions $1 \& 2$}

To analyse the collected data ANOVA was conducted. See table 3 for descriptive statistics.

Table 3: Descriptive statistics for different components of the reading test in different groups

\begin{tabular}{|c|c|c|c|c|c|}
\hline Group & $\begin{array}{l}\text { Reading } \\
\text { Comprehension Type }\end{array}$ & Mean \pm S.E & $S D$ & Skewnese & Kurtosis \\
\hline \multirow[t]{5}{*}{$\begin{array}{l}\text { High prof. } \\
\text { High } \\
\text { strategy }\end{array}$} & Literal comprehension & $0.72 \pm 0.03$ & 0.12 & -0.126 & -0.524 \\
\hline & Inferencing & $0.79 \pm 0.04$ & 0.18 & -0.380 & -0.672 \\
\hline & Reorganizing & $0.60 \pm 0.03$ & 0.15 & 0.0 & -1.059 \\
\hline & Vocabulary & $0.80 \pm 0.02$ & 0.11 & 0.0 & -0.692 \\
\hline & Total & $0.73 \pm 0.02$ & 0.07 & -0.087 & 0.027 \\
\hline \multirow[t]{5}{*}{$\begin{array}{l}\text { High prof. } \\
\text { Low strategy }\end{array}$} & Literal comprehension & $0.72 \pm 0.0$ & 0.13 & 0.473 & -0.054 \\
\hline & Inferencing & $0.60 \pm 0.05$ & 0.21 & -0.356 & 0.229 \\
\hline & Reorganizing & $0.58 \pm 0.05$ & 0.21 & -0.103 & -1.609 \\
\hline & Vocabulary & $0.61 \pm 0.02$ & 0.10 & -0.214 & 0.155 \\
\hline & Total & $0.63 \pm 0.03$ & 0.13 & -0.242 & $0.584-$ \\
\hline \multirow[t]{5}{*}{$\begin{array}{l}\text { Low prof. } \\
\text { High } \\
\text { strategy }\end{array}$} & Literal comprehension & $0.49 \pm 0.02$ & 0.11 & 0.075 & -0.375 \\
\hline & Inferencing & $0.40 \pm 0.03$ & 0.16 & 0.588 & 0.378 \\
\hline & Reorganizing & $0.38 \pm 0.04$ & 0.17 & 0.315 & -0.463 \\
\hline & Vocabulary & $0.50 \pm 0.01$ & 0.05 & 0.448 & -0.103 \\
\hline & Total & $0.43 \pm 0.02$ & 0.08 & 0.0 & -0.359 \\
\hline \multirow[t]{5}{*}{$\begin{array}{l}\text { Low prof. } \\
\text { low strategy }\end{array}$} & Literal comprehension & $0.46 \pm 0.02$ & 0.11 & -0.532 & 0.428 \\
\hline & Inferencing & $0.18 \pm 0.04$ & 0.18 & 0.779 & 0.210 \\
\hline & Reorganizing & $0.41 \pm 0.04$ & 0.17 & 0.504 & -0.012 \\
\hline & Vocabulary & $0.45 \pm 0.02$ & 0.09 & -0.286 & -0.628 \\
\hline & Total & $0.37 \pm 0.02$ & 0.09 & 0.899 & 3.240 \\
\hline
\end{tabular}

Table 4 below shows ranking of components of reading test items for different groups.

Table 4: Ranking of different components of reading test in different groups

\begin{tabular}{|c|c|c|c|c|c|}
\hline Group 4 & Group 3 & Group 2 & Group 1 & Index & Rank \\
\hline Literal & Literal & Literal & Vocabulary & Question type & \multirow{2}{*}{ First } \\
\hline 0.48 & 0.49 & 0.72 & 0.80 & Mean & \\
\hline Vocabulary & Vocabulary & Vocabulary & Inferencing & Question type & \multirow{2}{*}{ Second } \\
\hline 0.45 & 0.50 & 0.61 & 0.79 & Mean & \\
\hline Reorganizing & Inferencing & Inferencing & Literal & Question type & \multirow{2}{*}{ Third } \\
\hline 0.41 & 0.40 & 0.60 & 0.72 & Mean & \\
\hline
\end{tabular}




\begin{tabular}{rlllll}
\hline Inferencing & Reorganizing & Reorganizing & Reorganizing & Question type & \multirow{2}{*}{ Fourth } \\
\hline 0.18 & 0.38 & 0.58 & 0.60 & Mean & \\
\hline
\end{tabular}

To answer the first research question as, Is there any difference between the overall performance of different groups of combined general English proficiency and reading strategy use on reading comprehension test in English?' ANOVA test was conducted. (See table 5)

Table 5: Statistics for mean differences among the four groups

\begin{tabular}{|c|c|c|c|c|c|}
\hline Group & $N$ & mean $\bar{\mp} S . E$ & Std.deviation & $F$ & Sig \\
\hline Group1 & 19 & $26.11^{\mp_{0.57}}$ & 2.49 & \multirow{4}{*}{79.399} & \multirow{4}{*}{0.000} \\
\hline Group2 & 17 & $22.29^{\mp_{0.85}}$ & 3.51 & & \\
\hline Group3 & 23 & $15.83^{\mp_{0.44}}$ & 2.92 & & \\
\hline Group4 & 19 & $14.21^{\mp_{0.67}}$ & 5.54 & & \\
\hline
\end{tabular}

From the above table, and according to the observed $\mathrm{f}$ and $\mathrm{p}$-value, it became evident that the difference between the four groups in their overall reading score was significant. To test all pair wise comparisons among means to find where the difference exactly was, Tukey HSD post-hoc test was performed. Analysis of data showed the difference was significant between the first group and other groups. Group one outperformed other groups. The difference was also significant between group two and groups three and four. Group two outperformed groups three and four, but not group one. However, group three did not show any significant difference with group four. (See table 6)

Table 6: Sorted pairs grouped by significant differences using Tukey HSD post-hoc test

\begin{tabular}{llll}
\hline Group $i$ & Group j & Mean difference $(i-j)$ & Sig. \\
\hline Group 1 & Group 2 & $3.81115^{*}$ & 0.001 \\
\hline & Group 3 & $10.27918^{*}$ & 0.000 \\
\cline { 2 - 4 } & Group 4 & $11.89474^{*}$ & 0.000 \\
\hline Group 2 & Group 1 & $-3.81115^{*}$ & 0.001 \\
\hline & Group 3 & $6.46803^{*}$ & 0.000 \\
\cline { 2 - 4 } & Group 4 & $8.08359^{*}$ & 0.000 \\
\hline Group 3 & Group 1 & $-10.27918^{*}$ & 0.000 \\
\hline & Group 2 & $-6.46803^{*}$ & 0.000 \\
\cline { 2 - 4 } & Group 4 & 1.61556 & 0.239 \\
\hline Group 4 & Group 1 & $-11.89474^{*}$ & 0.000 \\
\hline & Group 2 & $-8.08359^{*}$ & 0.000 \\
\cline { 2 - 4 } & Group 3 & -1.61556 & 0.239 \\
\hline
\end{tabular}

As was mentioned earlier, according to the above table, group three had no significant difference with group four, but other groups showed significant differences in overall mean scores of reading test. The first group showed the most difference with group four. It was also revealed that groups one, two, three, and four ranked first, second, third and fourth, respectively, in their reading score. Further analysis was conducted to study if 
there was any significant difference between the mean scores of each of the components of the reading test in the four groups. (See tables 7 through 10) In fact, what follows answers the second research question formulated as, 'What is the pattern of performance on different components of reading comprehension test (literal meaning, inference, reorganizing, vocabulary) in different groups of combined general English proficiency and reading strategy use in English?'

To answer this question a test of ANOVA was run.

Table 7: Mean differences between different components of the reading test in the first group

\begin{tabular}{|c|c|c|c|c|c|}
\hline $\begin{array}{l}\text { Reading Comprehension } \\
\text { question type }\end{array}$ & $\mathrm{N}$ & mean $\mp 5 . E$ & Std.deviation & $\mathrm{F}$ & Sig \\
\hline Literal & 19 & $0.72^{\mp_{0.03}}$ & 0.12 & \multirow{4}{*}{7.871} & \multirow{4}{*}{0.000} \\
\hline Inferencing & 19 & $0.79^{\mp_{0.04}}$ & 0.18 & & \\
\hline Recognizing & 19 & $0.60 \bar{\mp}_{0.03}$ & 0.14 & & \\
\hline Vocabulary & 19 & $0.80^{\mp_{0.02}}$ & 0.11 & & \\
\hline
\end{tabular}

Based on the $f$ and $p$-value observed in table 7 , there was found a significant difference between the mean scores of different components of the reading test in group one. To find out where exactly the difference was, TukeyHSD post-hoc test was performed. Analysis of data showed the difference was significant between reorganizing and inferencing as well as between reorganizing and vocabulary. However, the difference was non-significant between other items. (See table 4)

Table 8: Means differences between different components of reading test in group 2

\begin{tabular}{|c|c|c|c|c|c|}
\hline Comprehension type & $\mathrm{N}$ & mean $\bar{\mp}$. E & Std.deviation & $\mathrm{F}$ & Sig \\
\hline Literal & 17 & $0.72 \bar{\mp}_{0.03}$ & 0.13 & \multirow{4}{*}{2.497} & \multirow{4}{*}{0.067} \\
\hline Inferencing & 17 & $0.60 \bar{\mp}_{0.05}$ & 0.21 & & \\
\hline Recognizing & 17 & $0.58^{\mp_{0.05}}$ & 0.21 & & \\
\hline Vocabulary & 17 & $0.61^{\mp_{0.02}}$ & 0.10 & & \\
\hline
\end{tabular}

Based on the $\mathrm{f}$ and $\mathrm{p}$-value observed in table 8 , there was found no significant difference between the mean scores of different components of the reading test in group two. 
Table 9: Means differences between different components of reading test in group 3

\begin{tabular}{|c|c|c|c|c|c|}
\hline Comprehension type & $\mathrm{N}$ & mean $\mp s . E$ & Std.deviation & $\mathrm{F}$ & Sig \\
\hline Literal & 23 & $0.49 \bar{\mp}_{0.02}$ & 0.11 & \multirow{4}{*}{3.433} & \multirow{4}{*}{0.020} \\
\hline Inferencing & 23 & $0.40^{\mp_{0.03}}$ & 0.16 & & \\
\hline Recognizing & 23 & $0.38^{\mp_{0.04}}$ & 0.17 & & \\
\hline Vocabulary & 23 & $0.47^{\bar{\mp}_{0.01}}$ & 0.05 & & \\
\hline
\end{tabular}

Based on the $f$ and p-value observed in table 9, there was found a significant difference between the mean scores of different components of the reading test in group three. To find out where exactly the difference was, TukeyHSD post-hoc test was performed. Analysis of data showed the difference was significant only between recognizing and literal meaning. However, the difference was non-significant between other items. (See table 4).

Table 10: Mean differences between different components of reading test in group 4

\begin{tabular}{|c|c|c|c|c|c|}
\hline $\begin{array}{l}\text { Comprehension } \\
\text { type }\end{array}$ & $\mathrm{N}$ & mean $\mp$ S.E & Std.deviation & $\mathrm{F}$ & Sig \\
\hline Literal & 19 & $0.46^{\bar{\mp}_{0.02}}$ & 0.11 & \multirow{4}{*}{16.570} & \multirow{4}{*}{0.000} \\
\hline Inferencing & 19 & $0.18^{\bar{\mp}_{0.04}}$ & 0.17 & & \\
\hline Recognizing & 19 & $0.41^{\bar{\mp}_{0.04}}$ & 0.16 & & \\
\hline Vocabulary & 19 & $0.44^{\bar{\mp}_{0.02}}$ & 0.09 & & \\
\hline
\end{tabular}

Based on the $\mathrm{f}$ and $\mathrm{p}$-value observed in table 10, there was a significant difference between the mean scores of different components of the reading test in group four. To find out where exactly the difference was, TukeyHSD post-hoc test was performed. Analysis of data showed the difference was significant between, a) inferencing and literal meaning, b) inferencing and reorganizing, and c) inferencing and vocabulary. However, the difference was non-significant between other items (for more information refer back to table 4 ).

\section{Phase two of the study for question 3}

Regarding the interview data analysis, when the student of the first group was asked what problems he had in reading comprehension, he answered his problem was in grammar and vocabulary. He would uncover hidden meanings by inferencing and believed strategies like guessing were very helpful. However, he thought general proficiency were very important or even more determining than reading strategies in 
successful reading comprehension. He believes strategies might help to solve reading problems but they might not always work.

Student from the second group mentioned he had a time management problem. He thought it was really an advantage to have a good command of English vocabulary knowledge, but he himself needed more processing time. He thought awareness and use of reading strategies could help him overcome his reading problem, but strategies like monitoring and evaluating were unknown to him and difficult to employ. That was why he was slow in reading.

Student from the third group stated he had vocabulary problems; he would use strategies such as guessing, but as his vocabulary knowledge was not good he usually got frustrated in the act of reading. To him knowledge of reading strategies was useless if there was no good command of English. He thought if he improved his knowledge of vocabulary and grammar, then reading strategies would help him go beyond the text.

Finally, student from the fourth group mentioned he was not good at reading. For this he had little motivation to read in English and did not like it. To him his main problem was in vocabulary and grammar. He believes for this reason he fails to get the literal message let alone the message beyond the text.

\section{DISCUSSION AND SUGGESTIONS}

Findings of this study evinced that different degrees of combination of general English proficiency and awareness and use of reading strategies would result in different outcomes in reading comprehension in L2. When both variables were at high levels in a reader, best results would be obtained. However, when this balance is disturbed the outcome might decrease by degrees as well. For example, if proficiency was high but awareness and use of strategies was low, there would be a significant decrease in reading performance in L2; or if L2 general English proficiency was low but awareness and use of strategies was either high or low, there would be a more significant decrease in reading performance in L2. However, there would be no significant difference between the group which was low in proficiency but high in awareness and use of strategies and the group which was low both in proficiency and awareness and use of reading strategies. It seems if the proficiency level is high having awareness and use of reading strategies is an advantage. However, when the proficiency level is kept low, high or low level of awareness of reading strategies is not a determining factor for higher performance in $\mathrm{L} 2$.

In addition it was found that ranking in different types of comprehension questions varied from one group to another. Based on the mean scores obtained, in group one the pattern from the highest to the lowest mean score was vocabulary, inferencing, literal comprehension, and reorganizing. However, in groups two and three the pattern was literal comprehension, vocabulary, inferencing and reorganizing. In group four, the pattern was literal comprehension, vocabulary, reorganizing, and inferencing. Analysis of data also showed a significant difference between the mean scores of each of the components of the reading test in the first group. Analysis of data showed the difference was significant between reorganizing and inferencing as well as between reorganizing 
and vocabulary. However, the difference is non-significant between other items. However, in the second group, there was found no significant difference between the mean scores of different components of the reading test. In group three, analysis of data showed the difference was significant only between recognizing and literal meaning. However, the difference was non-significant between other items. In group four, there is a significant difference between the mean scores of different components of the reading test. Analysis of data showed the difference was significant between a) inferencing and literal meaning, b) inferencing and reorganizing, and c) inferencing and vocabulary. However, the difference was non-significant between other items. What was more interesting was that it was only in the first group that students went beyond the surface literal meaning and had better performance in inferencing. In groups two, three, and four the participants had better performance on literal questions, and the lowest means in inferencing and recognizing type questions. However, in all comprehension type questions group one had mostly better performance compared to other groups. For example, in vocabulary comprehension questions, the mean scores in groups one through 4 were $0.80,0.61,0.50$, and 0.45 , respectively. In inferencing questions, the mean scores in groups one through 4 were $0.79,0.60,0.40$, and 0.18 , respectively. In literal meaning comprehension questions, the mean scores in groups one through 4 were $0.72,0.72,0.49$, and 0.48 , respectively. In reorganizing questions, the mean scores in groups one through 4 were $0.60,0.58,0.38$, and 0.41 , respectively.

The interview data also revealed that the student from the first group employed both linguistic proficiency and strategy knowledge to comprehend that text. Student from the second group had time management problem for reading the text effectively as some strategies like monitoring and evaluating were unknown. Student from the third group stated the root of his reading problem was vocabulary and grammar. To him knowledge of reading strategies was useless if there was no good command of English. Finally, student from the fourth group mentioned he had little motivation to read in English. Actually, he mentioned about the affective factor for his performance.

A plethora of studies on reading strategies have shed light on the positive contributions of reading strategies for successful reading in the L2 (Anderson, 1991; Ikeda and Takeuchi, 2003). On the other hand, to use reading strategies effectively, readers should reach a certain level of linguistic proficiency. Lack of linguistic proficiency is believed to short-circuit effective strategy use (Alderson, 1984; Koda, 2005; Perfetti \& Hart, 2001). Research (e.g., Oxford et al., 1993) also stresses the importance of the interaction between reading ability and language proficiency. However, high proficiency is not always a determining variable in coping with reading problems as students might feel perplexed and do not take an appropriate approach to foster their reading performance (Eskey, 2005; Phan, 2006; Shokrpour \& Fotovatian, 2009); All in all, the design of the present research and its findings are somehow different from the above mentioned studies as they did not investigate the combined effects of language proficiency and awareness and use of reading strategies. Based on the findings of this research, both of the variables should be emphasized as in this study it was observed that the best performance in reading is when the two variables are at high levels. However, a higher proficiency level seems to be more effective in reading comprehension than a higher 
level of strategy awareness and use as those who are at a high level in proficiency, regardless of level of strategy awareness and use score higher than those who are at a higher level of strategy awareness and use, regardless of level of proficiency. This does not imply that language proficiency should be given more priority to strategy awareness and use as both have been shown to play complementary role in reading performance. Given the significant contribution of proficiency and strategies to reading improvement, linguistic knowledge should be taught to learners simultaneously along with reading strategies. Students with high proficiency level should learn not to rely much on the linguistic knowledge and improve their awareness and use of reading strategies. The reverse should also happen so that fluent reading is guaranteed. It is recommended that English language teachers and learners do not overemphasize one variable over another and consider enhancing general proficiency level as well as awareness and use of reading strategies to have the most successful reading performance. It is also recommended that affective factors, along with proficiency level and strategy knowledge be considered in the teaching or learning process in reading classes.

Acknowledgement: This research work has been supported by a research grant from the University of Mazandaran

\section{REFERENCES}

Alderson, J. C. (1984). Reading in a foreign language: A reading problem or a language problem? In J. Alderson \& A. H. Urquhart (Eds.), Reading in a foreign language (pp. 122-135). New York: Longman.

Anderson, N. J. (1991). Individual differences in strategy use in second language reading and testing. Modern Language Journal 75: 460-472.

Brantmeier, C., \& Dragiyski, B. (2009). Toward a dependable measure of metacognitive reading strategies with advanced L2 learners. In C. Brantmeier (Ed.), Crossing languages and research methods: Analyses of adult foreign language reading (Vol. 7, pp. 47-72).

Day, R. \& Park, J. S. (2005). Developing reading comprehension questions. Reading in a Foreign Language 17: 60-73.

Eskey, D. E. (2005). Reading in a second language. In E. Hinkel (Ed.), Handbook of research in second language teaching and learning (pp. 563-580). Mahwah, NJ: Lawrence Erlbaum Associates.

Grabe, W. \& Stoller, F. (2002). Teaching and Researching Reading. Applied Linguistics in Action Series, Pearson Education.

Ikeda, M., \& Takeuchi, O., (2003). Can strategy instruction help EFL learners to improve reading ability? An empirical study. JACET Bulletin, 37: 49-60.

Koda, K. (2004). Insights into second language reading: A cross-linguistic approach. Cambridge: Cambridge University Press. 
Koda, K. (2005). Insights into second language reading: A cross-linguistic approach. Cambridge. Cambridge University Press.

Liu, D. (2004). EFL proficiency, gender, and language learning strategy use among a group of Chinese technological institute English majors. ARECLS-E Journals 1: 20-28.

Mokhtari, K., \& Perry, B. (2008). Using Rasch analysis to calibrate students' metacognitive awareness and use of reading strategies. In K. Mokhtari \& R. Sheorey (Eds.), Reading strategies of first- and second-language learners: See how they read (pp. 67-84). Norwood, MA: Christopher-Gordon Publishers.

Mokhtari, K. \& Reichard. C.A,. (2002). Assessing students' metacognitive awareness of reading strategies. Journal of Educational Psychology 94(2): 249-259.

Nisbet, D. L., et. al. (2005). Language learning strategies and English proficiency of Chinese university students. Foreign Language Annuals in Proquest Journal, 38(1): 100-108.

Oxford, R. L., et. al. (1993). Learning Japanese by satellite: What influences student achievement? System 21:31-48.

Perfetti, C. A, \& Hart L. (2001). The lexical basis of comprehension skill. In Gorfien, D.S., (Ed.), On the consequences of meaning selection: Perspectives on resolving lexical ambiguity. American Psychological Association; (pp. 67-86) Washington, DC.

Shokrpour, N., \& Fotovatian, S. (2009). The effects of consciousness raising on metacognitive strategies on EFL students' reading comprehension. ITL International Journal of Applied Linguistics 3: 221-245.

Urquart, A. \& Weir, J. C. (1998). Reading in a Second Language: process and product. London Longman.

Walczyk, J.J. (2000). The interplay between automatic and control processes in reading. Reading Research Quarterly 35 (4): 554-566.

\section{Turkish Abstract}

\section{İngilizce Okuma Performansinda Dil Yeterliği ve Stratejileri}

İngilizce (L2) yeterliği ve okuma stratejilerinin başarılı bir okuma performansında oldukça etkili olduğuna inanılır. Fakat, yapılan çalışmalardan çok azı bu iki değişkenin başarılı okumadaki birlikte etkisini araştırmıştır. Alandaki bu eksikliği gidermek için yapılan çalışmada 78 üniversite öğrencisi bu iki değişkene göre dört farklı seviye grubuna ayrılmıştır. Daha sonra bu gruptaki ögrencilerin verilen okuma testi ve yapılan bir mülakat sonrasında okumadaki problemlerinin ne kadarı dilsel yeterlikten ne kadarı stratejik yeterlikten kaynaklandığ belirlenmeye çalışılmıştır. Bulgular yüksek genel yeterlik seviyesinin yüksek dikkatle bağlantılı olduğunu, okuma stratejilerinin kullanımının yüksek performansla sonuçlanacağını ve farklı okuma sorularına 
verilen cevapların gruplara göre farklılaştığını göstermiştir. Sonuç olarak okumayı anlamada en iyi performansı almak için her iki değişken de aynı şekilde vurgulanmalıdır.

Anahtar Kelimeler: Birleştirilmiş etki, Dikkat ve strateji kullanımı, Dil yeterliği, Okuma stratejileri, Okuma performans1

\section{French Abstract}

\section{Compétence Linguistique et Stratégies sur Performance Lisante en anglais}

L'anglais général (L2) la compétence et la lecture de stratégies est supposé être fortement effectif dans la performance de lecture réussie. Cependant, des études disponibles examinaient rarement les effets combinés de ces deux variables sur la lecture réussie. Pour remplir cet écart, 78 étudiants universitaires ont été divisés dans quatre groupes de degrés différents de ces deux variables dans L2 et donné un test lisant en anglais et un entretien pour évaluer quelle part de problèmes de L2 lisant parmi les quatre groupes ont été enracinés dans la compétence linguistique et-ou la compétence stratégique. Les découvertes l'ont montré le haut niveau de compétence général couplé avec la haute conscience et l'utilisation de stratégies lisantes aboutirait l'à la meilleure performance et que le modèle de réponses aux composants différents de question lisante est différent dans des groupes différents. On le conclut que les deux variables devraient être soulignées simultanément pour la meilleure performance dans la compréhension lisante.

Mots-clés: Effets Combinés, Conscience et Utilisation de Stratégies, Compétence de Langue, Lisant Stratégies, Lisant Performance.

\section{Arabic Abstract}

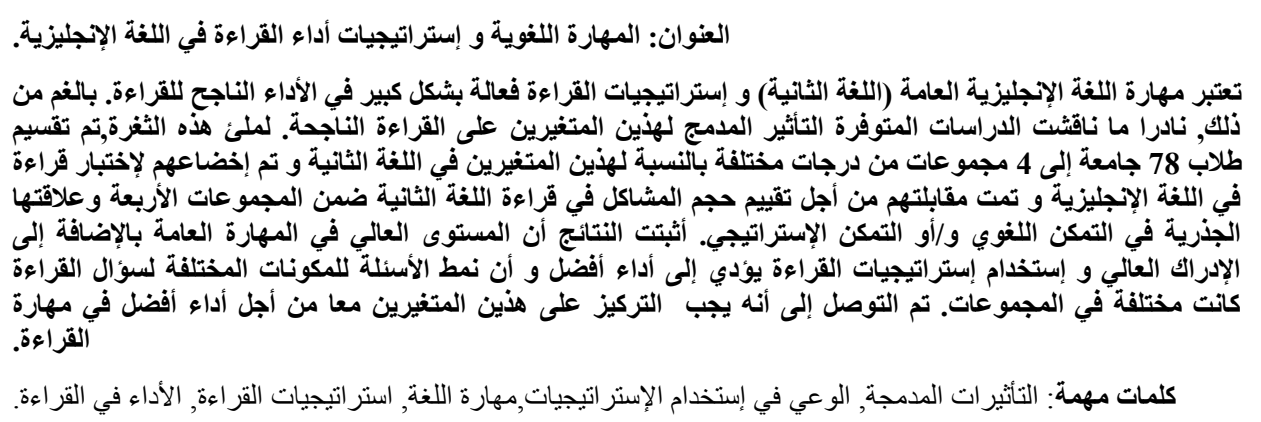

